\title{
PLANNED AND UNTOLD STORY OF THE CITY'S ARCHITECTURE: THE PRE-INDUSTRIAL PLAN FOR THE RIVERSIDE BOUNDARY OF LISBON, PORTUGAL - MATERIALIZED AND REMAINING ASPECTS OF CARLOS MARDEL'S PLAN FROM 1733
}

\author{
ARMÉNIO DA CONCEIÇÃO LOPES \& CARLOS JORGE HENRIQUES FERREIRA \\ CIAUD, Lisbon School of Architecture, Universidade de Lisboa, Portugal
}

\begin{abstract}
Vitrúvio establishes at DeArchitectura the principles of design and port construction to serve the city in nautical, commercial, warlike and architectural terms. Alberti retakes the concept and extends it. As far as we know, Lisbon never possessed, during classical antiquity, a port worthy of that name, as Vitruvius described. The justification for the absence of a port's structures can be due an exceptional characteristic as the natural anchorage - ships are protected in Tagus even in stormy days, away from the sea. Here only the tides have effect, by the minor winds and curling/ripples, not obliging thus to the design/construction of the port as it happens in other maritime cities. The Tagus is a pleasant cove - "Olisipo", interior sea. Francisco de Hollanda planned the city in accordance to the river, assuming it as an essential raw material of the locus. The image of the city is strongly linked to the aquatic environment. Tagus's importance to the city is reinforced by Frei Nicolau de Oliveira in the "Lisbon Book of Greatness" - a strategy relocating peninsula's capital to Lisbon; citing the Emperor Charles V: "If I had been King of Lisbon, quickly I would be of the world". Following the words of King Charles V (I of Spain), King Philip II promoted works in view of Tagus' navigability, intending to link Madrid to the Atlantic. It was up to the architect Carlos Mardel, the delineation of the desires of the Portuguese monarch, King D. João V, to create the "Atlantic-Rome". The new plan, for the riverside front of Lisbon, redesigned the land-water frontier, suggesting a modern image and new port infrastructures. It was interrupted abruptly by the earthquake in November 1, 1755, and it erased, from the urban history of Lisbon what would be the largest pre-industrial plan for the city - one of the greatest for Europe at the time.

Keywords: Lisbon, Carlos Mardel, preindustrial plan, pre-earthquake plan of 1755, riverfront architectures, maritime city planning, water city design.
\end{abstract}

\section{INTRODUCTION}

The intention of this study is to evaluate the ways of appropriation of the Lisbon riverfront, between Praça do Comércio and Praça de Santos, and Alcântara. Its preindustrial development and its post-earthquake influence.

The aim is to highlight the importance of the intangible heritage (written, drawn, in the field of the project and its practice), the way of thinking and designing preindustrial city, as the basis and source of inspiration of the current built heritage. As immaterial pieces of this city architecture are the ancestral plans, the theory and practice of the project at the time, and the possible reflections of these delineations and ideas in the current buildings.

The aptitude of the city, its locus, its Genius Locci, will probably be established in the city's first major urban design (Carlos Mardel project) combined with the wishes of King D. João V (the Portuguese "Sun King") to the "New Rome of the West". This is a new city project, including changing the center of political power to the west, a truly architectural city project. 
However, thrown to the deepest corners of the city's memory, have or not been incorporated in the city some assumptions from that plan? Will they still exist today, some of the aspects of its design that may have been (explicitly and implicitly) used during postearthquake reconstruction?

Based on the analysis of the relationship between the pre earthquake plans (not implemented, in concrete terms), the riverfront, and the built heritage, we intend to verify the extent to which the former have a relationship with the present. If so, to what extent, by what metrics and assumptions they have been materialize in the current architecture (ex.: Baixa Pombalina). These pieces of design acquire the patrimonial and historical value of the city itself, since this is its territorial support of project. As such, they will be references of memories and various stimuli. To analyze and evaluate them, from the point of view of the planning of the riverside city (the waterfront of Lisbon) is the aim of this study.

\section{THE TRATADISTICS AND THE DESIGN OF THE CITY OF WATER}

Through its main treatise (Marcus Vitruvius Polio), the classical antiquity transmitted the premises that should emerge for the design of the port city - outlined in conjunction with the design of the port. Based on the definitions of Vitruvius, there is no indication that a port structure (maritime port) has been built in Lisbon to set out the design and architecture of the city.

However, there are reports of structures, whose exact size is unknown, as well as its characteristics, specific functions, and urban environment. These have been found at different moments in the history of Lisbon, which indicates that [1] "This huge tidal creek (...) had already been one in Roman times. It is said that in 1571, when the foundations were laid down for a new dormitory in S. Domingos, the remains of a dog with excellent stonework and bronze hoops for mooring the vessels were found there, just like the Romans used them."

According to "Carlos Antero Ferreira, in 1541 Pedro Nunes (1502-1578) should translate the difficult De Architecture de Vitruvio into Portuguese, as revealed in the introduction of his "Tratado dos Crepúsculos' ('Twilight Treaty')" [2]. However, without implementing changes in the building assumptions of the riverside either at the height of the building or in terms of the maritime port infrastructure - as far as is known. Although in the 16th century there were already times of effective overseas maritime activity in Portugal, once intense trade developed by sea, port structures would be crucial for a city with this type of location and maritime dynamics. On the other hand, the awarding of the classification as "Roman anchorage" [3] excludes the existence of large port structures, at least in the broadest sense of the concept established by Vitruvius and taken up by Alberti.

The very Lisbon toponym of the classical period (probably of Phoenician origin "Alis-Ubbo", which designates it as a "pleasant cove", a toponym adapted by the Romans to "Olissipum" and / or "Olisippo"), points to this physiographic characteristic since ancient times. This fact supports what is known to us from descriptions and engravings dated back to the 16th century. The banks of the city (the banks of the river - the riverside), with its small tidal variations, provided natural conditions for the picking up of goods. This change in the water levels was easier to control through navigation and allowed a constant use of the river by means of beaching.

For all these reasons, Lisbon had such exceptional characteristics as an anchorage, the "soft cove", and hence the creation of heavy port structures was "waived": "the port material traces, that is constructions such as wharfs, docks, constructed boating ramps (...) may actually never have existed in places with port functions" [4]. Thus, due to the natural aptitude of the locus, one may conclude that these infrastructures did not existed or were unknown. 
This apparent lack even led some national and foreign authors and descriptors to make less favourable accounts of the characteristics and conditions of the city's waterfront not only at that time but also in subsequent centuries. Francisco de Holanda (1518-1584; originally "Francisco d'Olanda") in his work entitled "Da Fábrica que falece à cidade de Lysboa" [5] ("From the dying Factory to the city of Lisbon" - that is, from the buildings that Lisbon lacks and needs) points out the various needs with a clear mention to maritime issues - Fig. 1 . Coming from Rome, the author carries with him the first major references to the eternal city and his attempt at semblance to Lisbon. The connection to the river, water and waters is based on the first assumption of the design of the city.

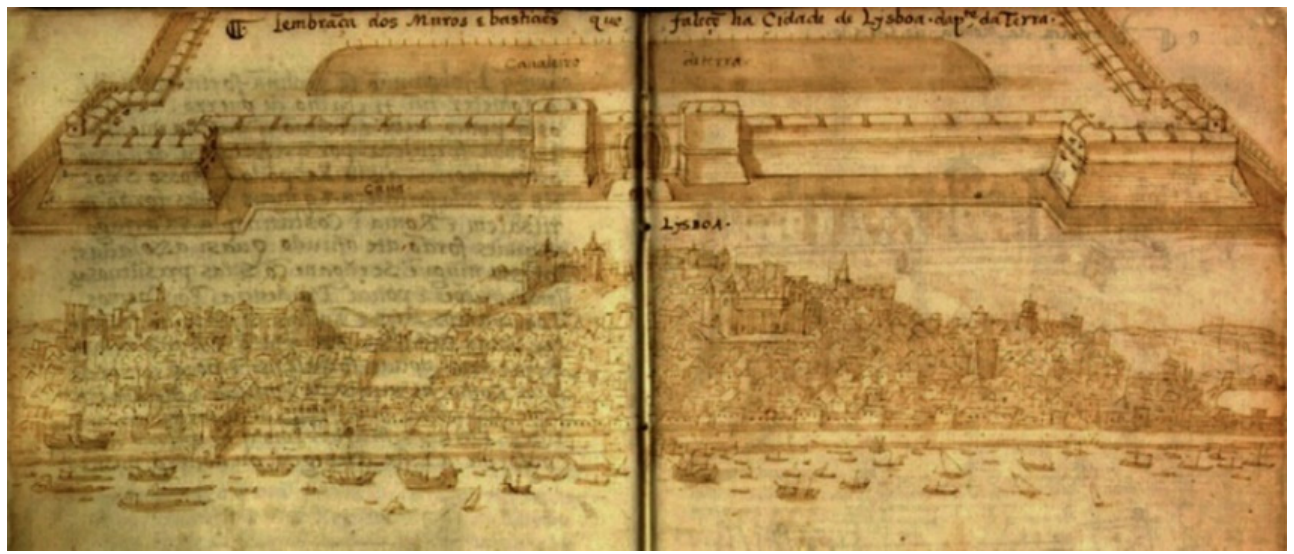

Figure 1: Lisbon by Francisco de Holanda [6].

António Ribeiro Sanches (1699-1783) in his "Tratado da Conservação da Saúde dos Povos" ("Treaty on the Conservation of Peoples Health") sets out the best characteristics of the city's location. He makes a relevant reference to the proximity and connection the city may have to the sea and the river, taking advantage of these. It recognises that "All known nations always seek the river banks to found settlements: they earn their livelihood from them; they save through hard work and a lot of fatigue during sailing: they lead to the fertility of the land; and it is certain that if they knew how to take advantage of such places Nature so generously offers them, they would turn their dwellings and their life into something delicious (...)" [7]. Supported by the treatise, he mentions that "According to cited Baptista Alberti, a town or village should not be found so close to the sea, so that the least damage may be received from it... The same caution should be given when the founding of villages near large rivers, lakes or large tanks is needed" [7].

Ever since the treatise, the riverside locus close to the sea but not beside it seems to be a special advantage. The proximity of the water element as a source of supply (good water from springs and streams), navigability, anchorage, combined with an elevated area for defence and protection are excellent physiographic elements that greatly value the locus. Lisbon brings together several of these key advantages. The city will remain intrinsically linked to its locus - Fig. 2.

The importance of the River Tagus as a means of fluvial and maritime connection extends far beyond the city limits and the limits of the national territory. The various ports of the River Tagus and its subsequent attempt to connect them to Madrid prove their importance in the territory of the Iberian Peninsula. This aspect is reinforced by Frei Nicolau de Oliveira 
(1566-1634) in his "Livro das Grandezas de Lisboa" ("Book of the Greatness of Lisbon") (1620) in which, in a strategy of relocating the capital of the peninsula to Lisbon, under Filipino's rule, and addressing King Filipe I from Portugal, he says: "This is how Emperador Carlos V, your grandfather, understood this (when he saw the help Portugal gave him in the capture of Tunez) that said: had I been King of Lisbon, in no time would I have been ruling the whole world" [8].

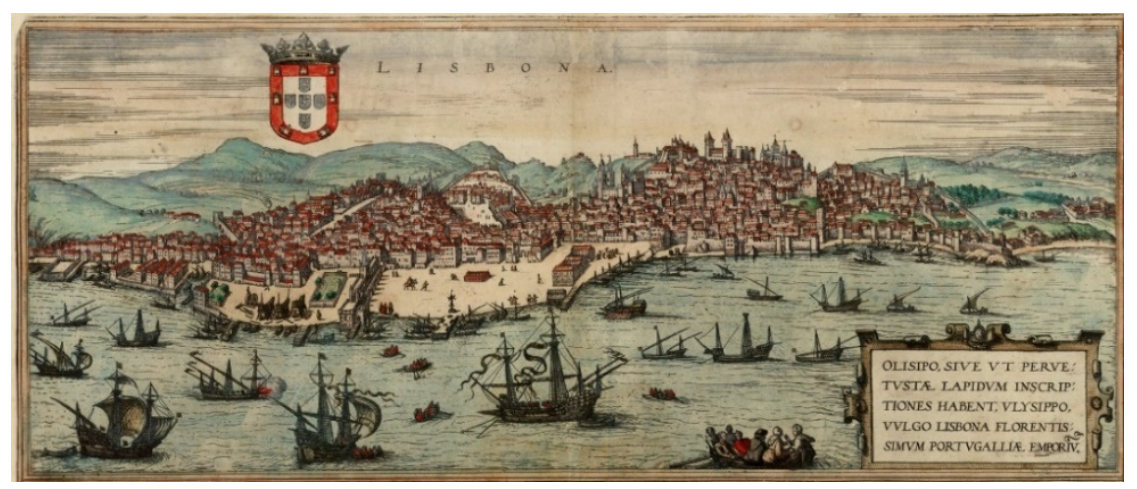

Figure 2: Lisbon in the Civitates orbis terrarum, Vol. 1, Cologne, $1572-1617$, by Georg Braun; the drawing may be from the reign of King D. Manuel (1495-1521).

Appealing the union of the two Iberian kingdoms Manoel Severim de Faria (1584-1655) states that "for the conservation and increase of the Monarchy of Spain it will be important to assist His Majesty with his Court in Lisbon" [9]. In this speech he lists a number of reasons such as the size of the city, the purity of the air, the excellence of the "most capable and safer port all over Europe', the shipyards 'which become enormous galleons in it, and the ships from India which are the largest vessels sailing the sea nowadays."

Following the same reasoning, Luiz Menezes de Vasconcellos (1542-1623) mentioned the high availability of the materials for the construction of vessels, so that the Iberian monarch's court could establish themselves in Lisbon: "the city of Lisbon is most suitable for the things related to the sea (...) than any other, and which it will have abundantly in it (...), and El-Rei the best recreations that one can wish for... this city is the worthiest of all, from your assistance" [10].

Although throughout its history Lisbon did not have heavy port infrastructures that directly implied the design of the city, it did not draw itself (as a city) from the water. However, the relation between the city of water and its architectures will constantly live from this connection, since the "dialogue between landscape, architecture and water is one of the main poetic visions and interventions between nature and architectural artefacts that intentionally linked with water can obtain real and imagined meanings" [11].

\section{ARCHITECTURE AND MODERNITY OF THE RIVERFRONT}

Moment by moment the architecture of the city settled in the navy territory. However, to the best of our knowledge, a plan for the city from its maritime needs - or that would combine such valences - was never drawn up. Until the very first time in which a strategy for the river front has been defined, the works were developed occasionally without a joint or comprehensive unit, and without predefined delineation that comprised the connection of the city to the water as a whole. 
The initiative to develop the first project worthy of the name was attributed by Adolpho Loureiro (1836-1911) to the Portuguese King D. João V (1689-1750). For the port of Lisbon, he [12] even points out that "(...) they should make it an unrivalled port in the world. So good would it be that maybe one would think that art could never have done better than nature had already done. Thus, everything was limited to small works restricted to one point or another, without subordination to a carefully assessed general plan. The time had come when ships crammed with gold, spices, and all that the East and West Indies could give us entered our bar, and the higher the treasury yielded, the greater the fever was to spend all that gold in monumental and ostentatious works. It is not surprising then that D. João V was given the first general and methodical project for the improvement of the port of Lisbon."

Its reign pointed to cultural and historical aspects with a special historical and cultural value, "The Portuguese eighteenth century was not badly herald from the point of view of knowledge and preservation of antiquity: under the advice of the Royal Academy of History, on 20 August 1721 D. João V signed a charter banning the destruction of buildings, statues and marbles or signs of 'Phoenicians, Greeks, Persians, Romans, Goths and Arabs"' [13].

The Portuguese "King Sun" known as "Magnanimous" was a lover of the arts and culture, and apart from defining a strategy for the Holy Church he had a special appreciation for Rome. Aspects of varied order, such as artistic, historical, religious, made the ancient empire capital a constant source of inspiration and knowledge. The Portuguese monarch's fascination with the eternal city was evident and he even had idealised to make Lisbon the new Rome of the West - the Atlantic Rome. Such a company lacked a well-defined and thought-out plan. Under these assumptions, Lisbon's connection with the river and the sea was an advantage.

The first major plan for Lisbon was defined from the water. It established itself by connecting the city to the river and sought to regulate its riverfront through drawing. Outlined by the Hungarian Military Engineer and Architect Carlos Mardel (1695-1763), who served in the Portuguese Army as an architect of the royal palace, it actually received the royal seal due to its size and proposal.

The future occupation of Lisbon's riverside - a linear outline of a new city front - which sets out something totally new: the inclusion of water in the dialogue with the commercial, military, and playful dynamics (through the design of a new and hitherto non-existent 'riverside public walk') - will be made, as one might expect, with a social class that would be placed on an equal footing with the political, mercantile, and statutory powers that were in the first line of the city (the centre of power and commercial trade). The King himself had also planned the transference of the royal area to the Western part of the kingdom's capital: "Outside the city boundaries, but on the same side of the river and closer to the sea, Bethlehem was transformed into a recreational resort for the court. Between 1726 and 1729 the king bought six farms near the Jerónimos Monastery, which he combined into a single estate. Some courtiers followed his example and erected houses on the river fronts and surroundings (...). The Belém area has quickly became a true palatine river front" [14].

This fact, combined with the existence of such a plan for the city's "new riverfront", allows us to foresee various premises and assumptions that would make Lisbon a "new" city in the light of the modernism of that time and its worldwide projection.

The plan laid down a new urban line in front of the most densely populated area of the city, and it only defined the walking and garden area where the manor estates were already settled. Here the new bourgeoisie should establish its relationship with power and the new urban plan by means of a natural and effective monumentally of social and economic affirmation. 
Eng. Adolpho Loureiro [15] describes that "Carlos Mardel's project consisted of a pier stretching from a point upstream of the customs, along a straight line to the 'Ribeira das Naus', leaving two large protruding dogs for landing, with stairs - one opposite the Customs and the 'Jardim do Tabaco', and another opposite the 'Paço Real'. It continued in two straight alignments and ended up in the front of Esperança Square (Santos). It set out an avenue along it with new dwellings, creating a large square with a parochial church, which would be on the ground nowadays occupied by the Santos garden to 'Avenida D. Carlos', and with a monumental fountain in the centre. It would have an embankment in the middle that overlooked the river, with stairs, along with other small flights of stairs all along it. Before arriving at that new square there was a dock naturally intended for river boats with communication to the Tagus. The dog continued in straight lines with exterior stairs, accompanied by the same tree-lined avenue and with a side strip of land for buildings. After the folding of the 'Rock of the Count of Óbidos', a channel was to be found a little lower, which left to the side of the S., isolated from land, the new naval arsenal". Thus, the "first drawing stones" of the new Lisbon were launched, designed and projected from water for the first time in its history - Fig. 3 (i, ii, iii - the scan has divided the original into 3 sections).

This is the only pre-earthquake known Plan with Carlos Mardel's signature for the Lisbon riverfront (Lisbon city waterline - right bank of the Tagus River). According to Walter Rossa its dated from [16] "1733". Known as "Caes Novo Explanation, from the Belém marginal zone to the Santarém Quay”.
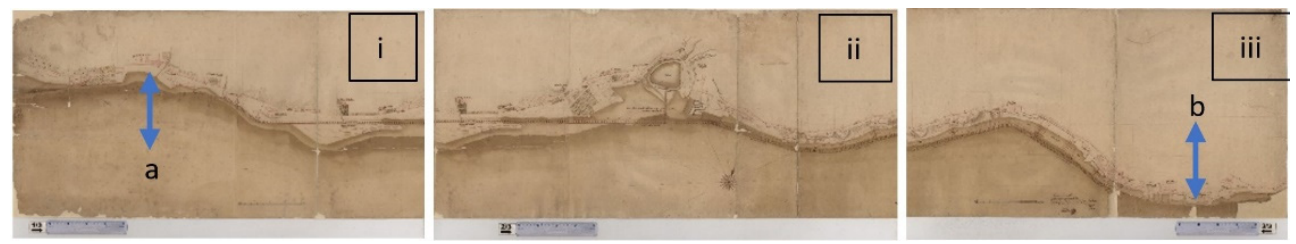

Figure 3: Carlos Mardel's Plan, dated 1733, dimensions: mm x $563 \mathrm{~mm}$. Territorial references: (a) Jerónimos Monastery; and (b) Royal Palace.

Until the present, no text or description of the plan is known. Apart from the author's signature, there is only a brief explanation. In this short text, some functional aspects of the plan are revealed - Fig. 4, by the legend's explanation: (left) "a: Streets to communicate with the wharves", "b: Channel between the streets for the river communicate with its doors", "c: Houses that can be built upon the new moorage"; (right) "Place where can be manufacture a river wharf for ships with all its dependencies" and, under the boulevard area, "Wharf with stairs".
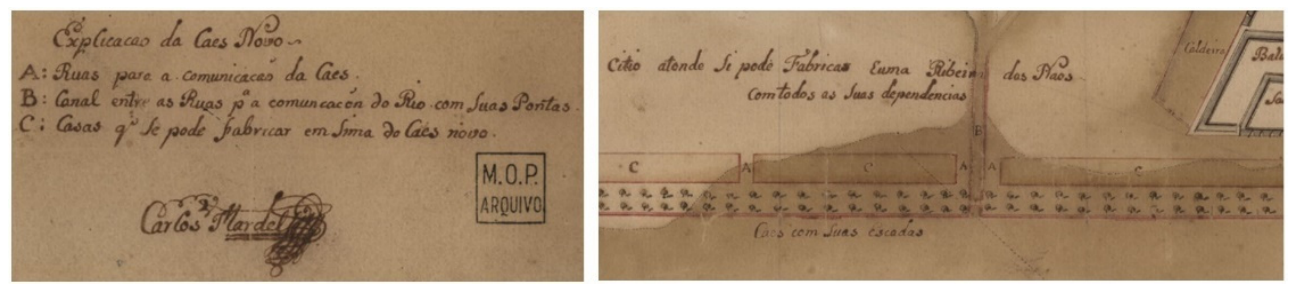

Figure 4: Two excerpts from Fig. 3. Captions of Carlos Mardel's Plan for the Lisbon Riverfront. 
The major importance of this riverfront project is that it is established as the largest known foreground, in extension, to the city of Lisbon. The outstanding aspects of this project alone act as elements of exceptional proposal for the city. A second built riverfront is created, in addition to the existing one, and the old riverside area is maintained between these, allowing water to enter through channels connecting the river to the projected interior jetties. Crowning the entire new waterfront, a tree-lined boulevard is established, a riverside promenade for the season, a green line by the waterfront - Fig. 5 .

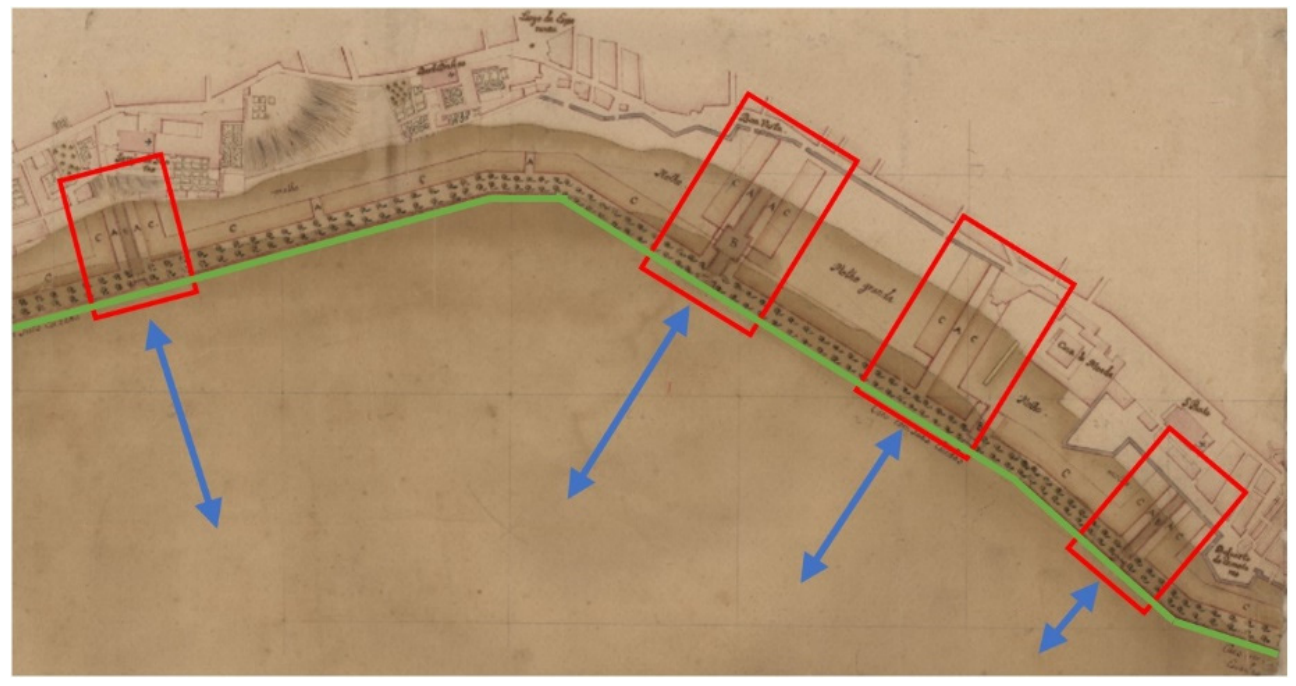

Figure 5: Excerpt from Fig. 3.

As mentioned, in the red rectangles most examples where the river connects to the city through waterways (blue arrows) are enlarged - the channels that Mardel sets out and defines, with the letter ' $\mathrm{B}$ ' being a "Channel between the streets for the communication between the river and its doors". The plan maintains the dynamics of the ancestral city with the river - the "sea/river gates" (the main connections, goods and people) that established their life with the maritime, river, fishing etc., and that were linked to the "old urban hull", are respected.

In addition to the strictly functional aspects, the potentiality of the locus, taken up, and laid down through the project, its design and its purpose, should be highlighted. The proposal thus provides for an effective dialogue between the city and the river. A first class "advanced" building is established, but it does not completely annul the water connection and the inherent activities. There is a concern to maintain them with the use of inland jetties and water passages - Fig. 6 .

The regulation of the margin is one of the solutions to secular claims, which constantly lamented the poor conditions of landing, linking and docking with Lisbon. Transverses and transshipments (loads and discharges) were assumed to be inevitable. It is even an intermediate dynamic between cargo ships and the river, having its own people and vessels for this purpose. 


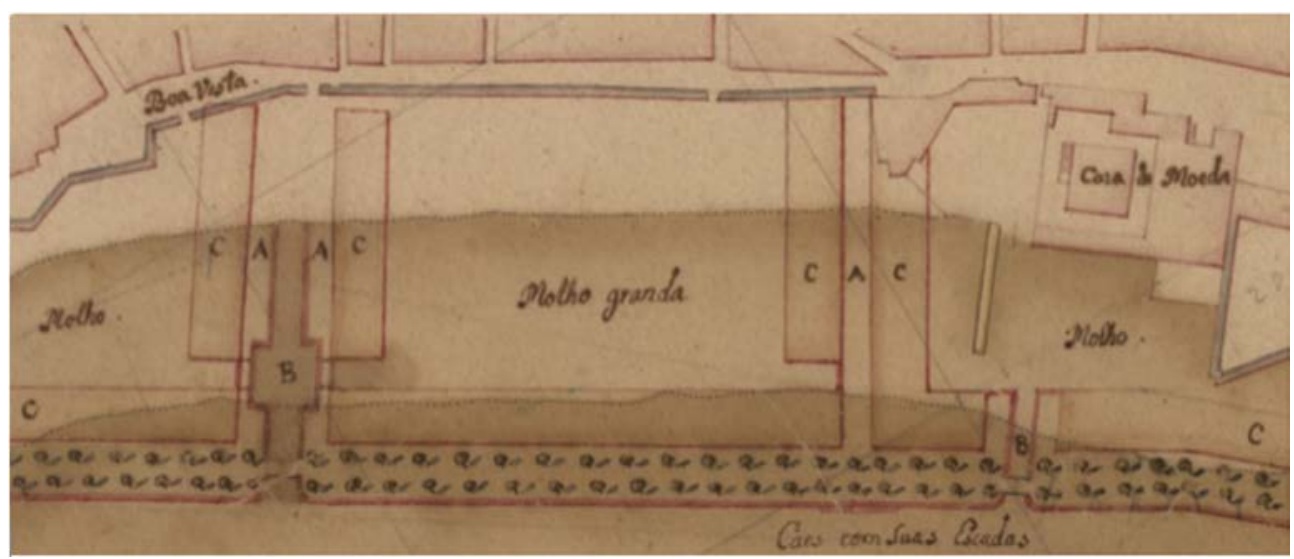

Figure 6: Enlarged excerpt from Fig. 3 - detail of the "big interior dike" area and two adjacent dikes.

In addition to the unique plan with the signature of Carlos Mardel, there is a "second version" - Fig. 7, referred to as "more advanced", given its characteristics, details, and various specifications that are added to the "initial plan". Squares where docks were foreseen arise, and the blocks defined linearly along the water line (only interrupted in the waterways) are subdivided into several modules, rectangular in shape and geometry, with dimensions very close to what would become the Baixa Pombalina.

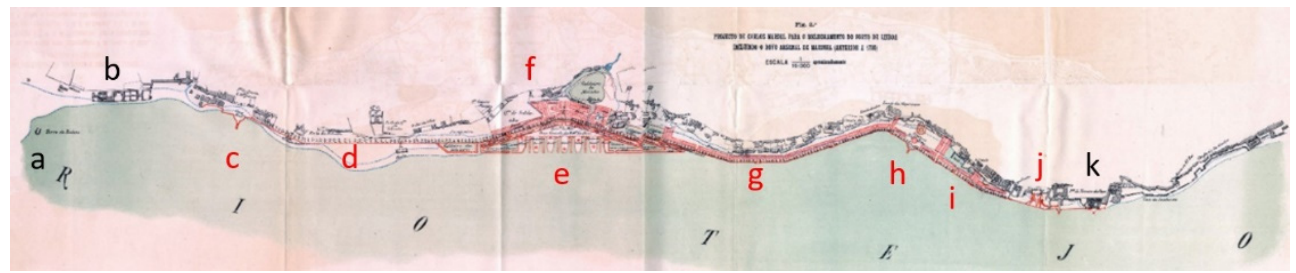

Figure 7: Carlos Mardel's Plan forward of Lisbon; version identified by Adolpho Loureiro [17] and corroborated by several authors. Legend: (a) Belém Tower; (b) Jerónimos Monastery; (c) new Belém pier; (d) tree-lined boulevard; (e) new ship docks; (f) new built nucleus; (g) new riverfront, adjoining waterfront buildings; (h) new square in "Boa Vista"; (i) wharf and interior dike; (j) docks; and (k) "Terreiro do Paço” (pre-earthquake).

The riverfront design is improved in the 2 nd version of the plan and elements with greater definition and detail are introduced. From the combination of two jetties a large square (letter h) emerges - with a larger width than the Terreiro do Paço and the later Praça do Comércio (Pombalina Imperial Square). In the Alcântara area, already in the middle of Western Lisbon (where the capital would grow), the proposal for the design of the new navy pier and two interior squares was materialised. 


\section{THE ARCHITECTURES OF THE WATERFRONT}

After the outlining of the new strategy for the modernisation of the maritime city to Lisbon, what image would the new river front have? A Baroque, Mannerism or Classicizing component? Or perhaps a "modernisation and updating" of the "Portuguese Chã architecture" [18]?

What remains of Mardel and king D. João V's plan for Lisbon's seafront? Two examples as the new squares, the first moment in Boa Vista (abandoned after the 1755 earthquake) and the second moment with Praça do Comércio (a solution for the area of political and economic power of reconstruction). Is it also possible to see it in the metrics, dimensions, framings, proportions, constructive systems, aesthetic languages and other elements, languages, and tracings that transited? Fig. 8, of epoch overlap is quite illustrative.

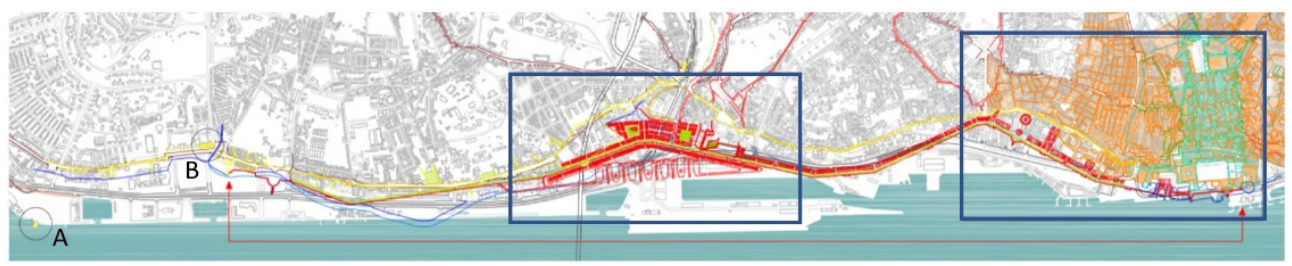

Figure 8: Subtitles/strokes - white/gray/blue: present; yellow: medieval road; orange: pre and post Pombaline traces; green: trace of the Baixa Pombalina after the earthquake; red: trace of Mardel's plan prior to the 1755 earthquake; (a) Belém Tower; (b) Jerónimos Monastery; Blue rectangles: Figs 9 and 10.

In the response to the order the language of the drawing suggests the pragmatism imposed by C. Mardel. As someone with recognised professional characteristics as an architect and an engineer, this allowed him to develop, through his school and training as a career military man, on the premises of the new Enlightenment winds, the relationship of the new Lisbon with its river - with the enormous "Sea Avenue" where one arrives and leaves from and to overseas.

The great Palatine Rome of the Atlantic was beginning to be shaped by the monarch's will and the architect's trait - with recognized valences for the connection between architecture and water - "In a letter attached to one of the copies of the Lisbon survey by Manuel da Maia, a high court official wrote that actually it would be very convenient to do in Lisbon what Emperor Diocletian had done in Rome 'with the applause of all'. As is well known, Diocletian (81-95) was primarily responsible for the main structuring of the Palatine housing complex. (...). In the context of a general emulation of Rome, these evocations of the Roman Empire were usual in the court of King John V. In a way, the reference to the Palatine is of the utmost importance to this text, as it is an unmistakable testimony of the intensions of the monarch for Lisbon. In short, this was the political and ideological context of D. João V's attempt at the urban reform of Lisbon: the fantasy of a "new Rome" [19]. The river waterfront would extend its referential power (political, economic, religious, and the new image) to the whole West Tagus front - Figs 9 and 10. Those were the mains guides for the new Lisbon before King John V's disease, and before the earthquake that would destroy most of the city central area (the actual city centre). 


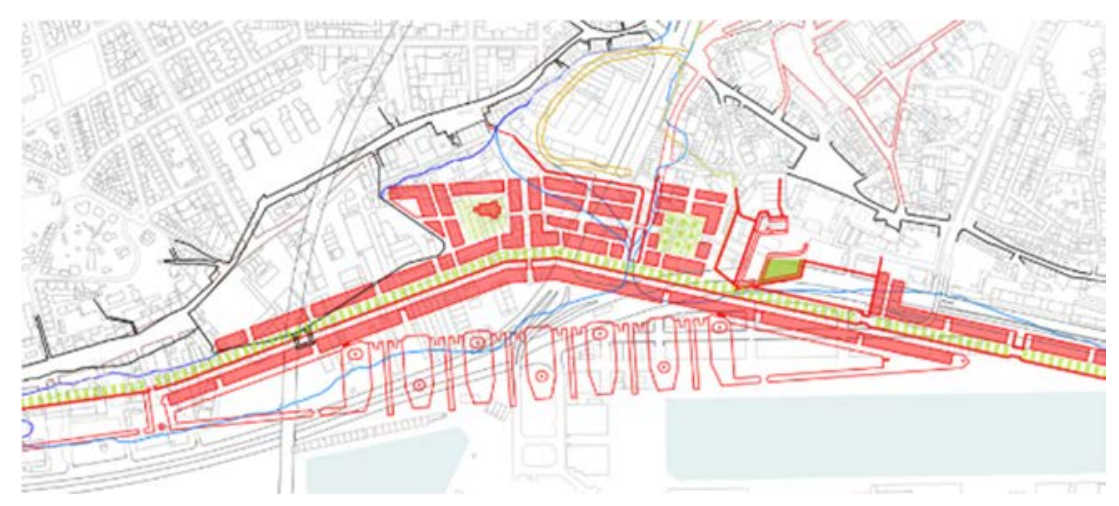

Figure 9: Detail from Fig. 8 - left rectangle, Mardel's Plan and the present.

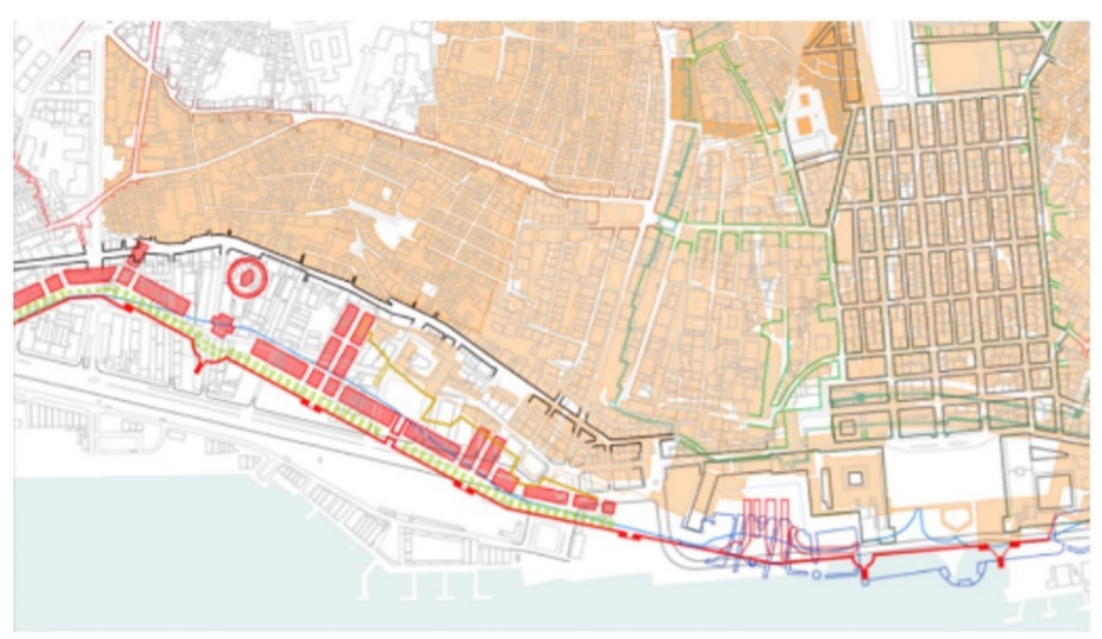

Figure 10: Detail from Fig. 8 - right rectangle, Mardel's Plan and the present.

After the earthquake, plans for the development of the city to the West were not immediately abandoned (even after the death of King John V). It was considered whether or not to continue developing it by the river. As José-Augusto França [20] points out "a proposal was made to leave the city in ruins, letting the owners do whatever they wished of her, and to build a new Lisbon to the West of the old city, on lands near the Tagus that were spared by the great earthquake. That was the most spoken idea, in order to protect the capital, once and for all, from similar disasters." So far there is no document drawn with these premises. Thus, the only known plan of this nature, with a planning for the Western zone, is the 1st and 2nd versions of Mardel's plan. The similarities of strokes, block delineations, street widths, among other elements of geometry / design, allow us to observe the semblance between these elements. Combined with the architectural components, the results of the post-earthquake programs have project reflexes, very similar to those defined by Mardel's plan. 
As for the new front built for the Tagus Bank, as far as we can determine, the Zenonian Laws of the Tagus view were not respected in the Mardel's plan, since the built front would prevent it, almost completely, depending on the elevation of the proposed buildings, parallel to the coastline. This apparent absence of guarantees by the Zenonian Laws of the Tagus was repeated during the plans for the reconstruction of Lisbon. Largely because of the new hygiene, public health and fire protection requirements.

From his work, political relations with the greatest Portuguese figures of that time, and regarding the time he spent in the country, we assume that the Hungarian architect would have thoroughly understood the Portuguese question, as it is reflected in his architecture due to the vicissitudes of time and of preference. These were the key aspects that allowed him to leave an effective mark on the national architectural scene, which still remains. Endowed with great professional rigor, he also demonstrated valences in different types of scale and work. The architect is associated with a spirit and a "Borrominesque technique" [21], which reveals a "solid" architecture, most surely from its German influences. Nonetheless, he gave it its own elegance, from which one can hardly identify influences within the European scene of that time.

\section{CONCLUSIONS}

The main issue is the assumption that, a priori, Carlos Mardel's Plan for the urban front of Lisbon is the first and last major preindustrial proposal based on the inclusion of the locus (genius-locci) of maritime aptitude, which had implicit a design, a city architecture. Based on its natural aptitude, it would materialize in an identity and character architecture, essentially of maritime nature. A water architecture, a riverside architecture, a "Luso Urbmarism".

Based on the assumptions identified, it is considered that Mardel's plan responds to a modern vision for the territory. Therefore, a project of expansion of the city through one new monumentality gets established. Bringing habitational functions to this waterfront in such an affirmative manner, defining a new way of designing the city - by the river - would imply, such a gesture and such constructions, to be marked with some, even if simple architectural decorum.

This supposed building ("the houses that can be built") within an eventual language that moves, between the Portuguese Chã architecture (plain architecture) and the depurated neoclassicism, would have on it the propensity for the decorative component. In addition to the monumentally there would also be the need to affirm the new city front, articulating the nautical and maritime component with a riverside scenery, through the planned wooded boulevard. However, while Carlos Mardel is recognized for his ability to handle different languages, his concern for the superfluous is not to be forgotten, and to come from a military-based author, as an engineer, in the service of the army.

At the heart of this assumption, it is noteworthy that the Engineer and Architect Carlos Mardel worked on the recovery of Lisbon after the earthquake, and that, among other projects, he was one of the team members who developed the winning proposal for the Lisbon Plan of Baixa Pombalina. This professional relationship allows us to point to the proximity of the Baixa image with the new proposals for the riverfront contemplated in its initial plan.

\section{REFERENCES}

Loureiro, A., Os portos marítimos de Portugal e ilhas adjacentes - Volume III, Parte I, Imprensa Nacional: Lisboa, p. 143, 1907. 
[2] Ferreira, C.A. \& Ayres, M., Tratadista do problema de Architectura civil no séc. XVIII Português, Separata da Revista e Boletim da Academia Nacional de Belas Artes, $3^{a}$ Série No. 7, Lisboa, pp. 19, 1987.

[3] Losada, R., Fundeadouro Romano em Olisipo, Documentário, [Consult.] https://documentariofundeadouroromano.wordpress.com/tag/porto-romano-delisboa/. Accessed on: 12 Aug. 2019.

[4] Bolt, M.L. \& Pinheiro, B.H., Os portos na origem dos centros urbanos - Contributo para a arqueologia das cidades marítimas e flúvio-marítimas em Portugal, Instituto Português de Arqueologia: Lisboa, p. 22, 2003.

[5] De Holanda, F., Da Fábrica que falece à cidade de Lisboa, Coord. José da Felicidade Alves, Livros Horizonte: Lisboa, 1984.

[6] De Holanda, F., Da fabrica que falece à cidade de Lisboa, 1571, Imagem: Faculdade de Arquitectura e Urbanismo de S. Paulo. http://lisboa-e-o-tejo.blogspot.com/2016/05/ iconografia-de-lisboa-1-parte.html. Accessed on: 12 Aug. 2019.

[7] Sanches, A.R., Tratado da Conservação da Saúde dos Povos, Universidade da Beira Interior: Covilhã, pp. 20-21, 2003.

[8] De Oliveira, F.N., Livro das grandezas de Lisboa, Impressão Régia: Lisboa, 1804.

[9] Faria, M.S., apud Sérgio, António, Antologia dos economistas portugueses (século XVII), Livraria Sá da Costa Editora: Lisboa, pp. 174, 1974.

[10] Vasconcellos, L.M., Do Sitio de Lisboa Sua Grandeza, Povoação e Comércio; Diálogos, Imprensa Régia: Lisboa, 1786.

[11] Gaspar, J., Os portos fluviais do Tejo, separata da revista Finisterra, Revista Portuguesa de Geografia, Vol. V-10, Centro de Estudos Geográficos: Lisboa, 1970.

[12] Loureiro, A., Os portos marítimos de Portugal e ilha adjacentes - Vol. III, Parte I, Imprensa Nacional: Lisboa, p. 158, 1906.

[13] Gomes, P.V., A cultura arquitectónica e artística em Portugal no séc. XVIII, Caminho: Lisboa, p. 67, 1988.

[14] Rossa, W., A Urbe e o Traço - uma década de estudos sobre o urbanismo português, Almedina: Coimbra, pp. 58-95, 2002.

[15] Loureiro, A., Os portos marítimos de Portugal, p. 160, 1906.

[16] Rossa, W., Lisboa: da busca de imagem de capital, Revista Rossio No. 5, Gabinete de Estudos Olisiponenses. www.cm-lisboa.pt/publicacoes-digitais/por-tematica?pub $=770$.

[17] Loureiro, A., Os portos marítimos de Portugal e ilha adjacentes - Volume III - Atlas, Imprensa Nacional: Lisboa, 1907.

[18] Kubler, G., A Arquitectura Portuguesa Chã. Entre as Especiarias e os Diamantes: 1521 - 1706, Editorial Vega: Lisboa, 1988.

[19] Rossa, W., A Urbe e o Traço, p. 95.

[20] França, J.-A., História da arte em Portugal - o Pombalismo e o Romantismo, Editorial Presença: Lisboa, pp. 13-14, 2004.

[21] Vasconcelos, F.T. de M. \& Mardel, C., Elementos para a história da arquitectura portuguesa do Séc. XVIII, Dis. de Licenciatura, Faculdade de Letras de Lisboa: Lisboa, p. 16, 1955. 